\title{
CORRECTION
}

\section{Correction to: An ethico-legal framework for social data science}

\author{
Nikolaus Forgó ${ }^{1} \cdot$ Stefanie Hänold ${ }^{2}$. Jeroen van den $\mathrm{Hoven}^{3} \cdot$ Tina Krügel$^{2} \cdot$ Iryna Lishchuk $^{2} \cdot$ René Mahieu $^{3,4}$. \\ Anna Monreale ${ }^{5} \cdot$ Dino Pedreschi $^{5} \cdot$ Francesca Pratesi $^{5,6} \cdot$ David van Putten $^{3}$
}

Published online: 22 May 2021

(c) Springer Nature Switzerland AG 2021

\section{Correction to: International Journal of Data Science and Analytics (2021) 11:377-390 https://doi.org/10.1007/s41060-020-00211-7}

The article "An ethico-legal framework for social data science', written by Nikolaus Forgó, Stefanie Hänold, Jeroen van den Hoven, Tina Krügel, Iryna Lishchuk, René Mahieu, Anna Monreale, Dino Pedreschi, Francesca Pratesi, David van Putten originally published electronically on the publisher's internet portal (currently SpringerLink) on April 10, 2021 without open access. The copyright of the article changed to $($ ) The Author(s) 2021 and the article is distributed under the terms of the Creative Commons Attribution 4.0 International License (http://creativecommons.org/ licenses/by/4.0/), which permits unrestricted use, distribution, and reproduction in any medium, provided you give appropriate credit to the original author(s) and the source, provide a link to the Creative Commons license, and indicate if changes were made.

The original article has been updated.

The original article can be found online at https://doi.org/10.1007/ s41060-020-00211-7.

Francesca Pratesi

francesca.pratesi@isti.cnr.it

Nikolaus Forgó

nikolaus.forgo@univie.ac.at

Stefanie Hänold

stefanie.haenold@iri.uni-hannover.de

Jeroen van den Hoven

M.J.vandenHoven@tudelft.nl

Tina Krügel

kruegel@iri.uni-hannover.de

Iryna Lishchuk

iryna.lishchuk@iri.uni-hannover.de

René Mahieu

Rene.Mahieu@vub.be
Publisher's Note Springer Nature remains neutral with regard to jurisdictional claims in published maps and institutional affiliations.

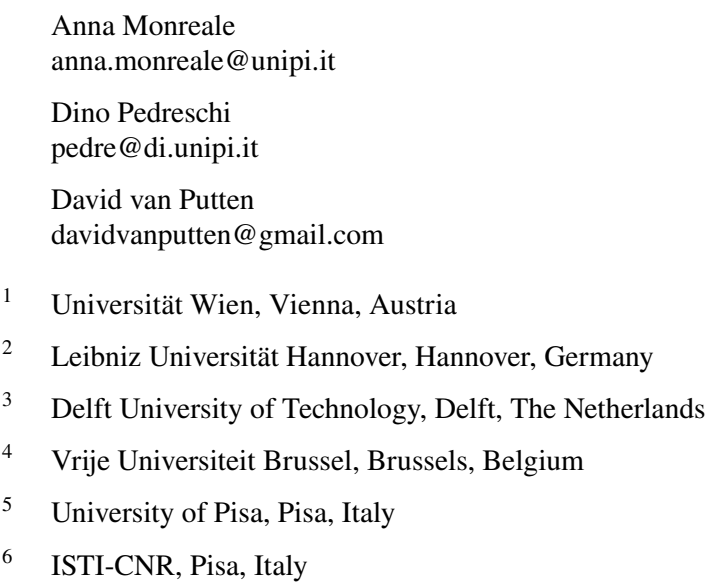

